\title{
Institutional quality and Economic Performance in the Southern African Development Community (SADC) Region: A Dynamic Panel Analysis \\ https://doi.org/10.36369/2616-9045/2021/v10i1a1
}

\author{
KHOLISWA MALINDINI \\ Wits School of Governance \\ University of the Witwatersrand \\ kholiswa.malindini@wits.ac.za \\ https://orcid.org/0000-0001-7082-4708
}

\begin{abstract}
The quality of institutions has increasingly become a key determinant of economic performance. This confirms a paradigm shift from the conventional macroeconomic determinants to governance as the crucial determining factor of economic performance, particularly in developing countries where economic growth is stagnant or moving at a meagre rate. With the aid of macroeconomic and governance data, this paper reports on an empirical analysis performed to quantify the impact of institutional quality on economic performance in Southern African economies over the period 2009-2019 by employing Generalized Method of Moments (GMM) technique with fixed effects. The empirical results indicate a negative and statistically significant coefficient for the governance index, inflation, and natural resources towards GDP growth. In contrast, trade openness, financial development, and domestic investment have positive and statistically significant coefficients. Based on the composite governance index, these results suggest that a weak institutional environment that aggravates corruption levels causes instability while also stimulating rent-seeking behaviour, which ultimately stifles economic performance in the region. Therefore, to attain inclusive and sustainable economic growth rates, the regional authorities should strengthen the law and enforce the rules.
\end{abstract}

Keywords: Institutional quality, SADC, economic performance, GMM, GDP

\section{Introduction}

For decades, economic growth has been the most crucial economic indicator through which macroeconomic objectives can be achieved and a backbone for all economies. It is at the heart of development policy. This powerful tool is a prerequisite for the economic development of countries, job creation, poverty alleviation, and even distribution of wealth and incomes resulting from an increase in the actual gross domestic product of the country. Economic models in the literature suggest that economic output is driven by 
physical capital, human resources, and technology (Solow, 1955). According to these models, labour and capital combined with technology warrant an increase in the country's gross domestic product per capita. Although some researchers concur with these theories (see Acemoglu \& Robinson, 2012b) - the models have been criticized for the narrow view of the determinants of economic growth - thus ignoring other possibly crucial factors that may directly affect sustainable growth (Siyakiya, 2017).

Within this context, the focus recently shifted from the conventional determinants of economic growth as outlined in the theoretical models to consider the role of institutions on countries' economic performance. Accordingly, institutional quality has increasingly become a key determinant of economic performance, particularly in developing countries where economic growth is stagnant or moving at a meagre rate.

Although the literature reveals that economic growth and institutional development are mutually significantly reinforcing in the long run, this paper argues that well-developed institutions induce economic performance and ultimately unlock the economic growth potential (Scully, 1988; Knack and Keefer, 1997; Henisz, 2000; Glaeser, La Porta, Lopez-deSilanes, and Shleifer, 2004; Acemoglu, Johnson, and Robinson, 2005; Acemoglu and Robinson, 2012; and Siyakiya, 2017). Thus, institutional development is the critical measure for fundamental development and long-run welfare establishment for all countries and regions. Irrespective of origin, economic growth remains a fundamental determinant of the short-run trajectory of countries; however, sound institutional development is a determining factor of the sustainability of short and long-run achievements of economies. Although, for instance, high-quality institutions may not inhibit an economic crisis, they create an enabling environment and coping mechanisms for society to recuperate from such crisis and continue its long-term trajectory of progress (Alemu, 2015; Aziz, 2018).

This paper is premised on the notion that 'institutions matter' for realizing socio-economic outcomes as they create incentives or constraints that shape human behaviour (Coase, 1937; Williamson, 1975; and North, 1990). Moreover, Acemoglu and Robinson (2012a), in their book "Why nations fail" argue that poverty, inequality and low economic growth levels are not the results of geographic locations or culture - but the variation in living standards globally, and are rooted in the nature and quality of institutions that exist in those parts of the world. These authors further argue that institutions form poor or good governance through political, social, and economic policies framed and implemented in countries. Thus, institutions are fundamental to the success or failure of economies. Consistent with this, Masuch and Moshammer (2016) reveal that varying levels of institutional quality is a potential contributor to incapacities experienced by European Union countries and inhibits inclusive growth.

Several scholars concur with this notion, for instance, Mauro, (2008); Knack and Keefer, (1997); Barro (1994); Kaufmann and Zoido-lobatón (1999); Aron (2000); Acemoglu, Johnson, and Robinson (2005); Easterly and Levine (2003); Rigobon and Rodrik (2004); Aysan, Nabli, and Véganzonès-Varoudakis (2006); Javed (2011); Kandil (2009); and 
Tylecote (2016). Consistent with this, Aron (2000) asserts that neglecting the quality of institutions makes it difficult to achieve sustainable and all-encompassing growth - in the same breath, Acemoglu \& Robinson, (2012) add that unless inclusive institutions exist, sustainable growth remains impossible. Interestingly, the African Economic Research Consortium (AERC), (2006) echoes the same sentiments outlining that institutional quality explains variation in the growth of African economies.

It is within this context that this paper seeks to examine the effect of institutional quality on economic performance in the SADC region, which has been struggling for growth. For instance, the economic outlook report reveals that since 2016, the region's economic growth has averaged 1.9 percent, and this trend continues giving rise to the unemployment rate, inequality, poverty, and unsustainable public debt levels. In contrast, Asian economies have been growing faster at about 7.5 percent (Tralac, 2019). Thus, lower growth rates may be a consequence of institutional weaknesses in the continent; these may include, amongst other things, inadequate formulation of laws, regulations and policies, or lack of enforcement of the rules. Crawford (1995) asserts that Africa's institutional weaknesses emanate from the effects of colonial rule, which had little incentive to develop Africa's local institutions - Acemoglu and Robinson (2012) also point out that the failure or prosperity of nations depends on the type of institutions which historically take root. Thus, the purpose of this study is to examine the extent to which institutional quality impacts economic performance in the SADC region and to identify governance indicators that significantly explain variation in economic performance.

To this end, the remainder of the paper is structured as follows: Section 2 presents a brief literature review regarding the institutional quality and economic performance; Section 3 presents an overview of economic growth in the SADC region; Section 3 presents the methodology adopted, the estimation techniques and the data sources utilized; while Section 4 presents empirical results and interpretation; Section 5 evaluates findings, draws conclusions, and presents policy recommendations.

\section{What are institutions?}

Institutions became increasingly popular in academic research following Coase (1937), Williamson (1975) and most importantly, North (1990)'s seminal work- these scholars emphasized that institutions do matter since they create incentives that shape human behaviour - and are susceptible to analysis. Moreover, these researchers understood institutions as a type of social structure - 'humanly devised in nature' (North, 1990). Finally, they recognized that human interaction is regulated by 'implicit rules' and thus combined economics and social sciences such that economic institutions become a broader process for traditional development.

Although popular, there is still no consensus regarding the definition of institutions; however, this study adopts North's (1990:5) definition as it refers to institutions as the 'rules of the game, the 'humanly devised constraints that structure human interactions' 
these include formal rules and informal constraints which shape human behaviour. Therefore, the 'rules of the game' are endogenously created through the strategic interactions of agents and cannot be imported from other countries. According to the literature, formal rules consist of fundamental rules, legal systems, and institutional environments. It is through an institutional environment that institutional arrangements are created between individuals and organizations to manage activities.

\section{Institutions and economic development - which one should come first?}

Although there has been a consensus in the literature concerning the correlation between institutional quality and economic performance, there is still an ongoing debate on whether institutions drive economic performance or the other way around. For instance, while Acemoglu et al. (2005), and Hall \& Jones (2013), Easterly \& Levine (2003) and Bruinshoofd (2016) support the notion that institutions drive economic progress by shaping the context within which economic outcomes are derived - Glaeser et al. (2004) vigorously support the reverse connection. According to Acemoglu et al. (2005), the institutional quality impact is contextual and provides an enabling environment for growth when sufficiently high quality or hampers growth if the opposite happens. Further, Hall \& Jones, (2013) believe that high-quality institutions drive the total factor of productivity in a country. This view is based on the belief that efficient, well-developed, and corruptionfree institutions guarantee that labour can only be used for productive purposes and not wasted in rent-seeking activities, which lead to higher economic growth (North, 1990). Furthermore, Good quality institutions enhance the ability of a country to adopt new technologies, which may play an essential role in upgrading the development process of a country (Bernard \& Jones, 2019) Some scholars argue that good institutional quality is the only condition for economic convergence.

Contrary to this view, Glaeser et al. (2004) argue that high levels of economic development allow economies to adopt high quality and inclusive institutional arrangements. These authors believe that countries should strive for economic prosperity first, and only when it has been achieved should countries worry about inclusive institutions.

Given the two sides of the debate, this study argues that sound institutional quality drives economic prosperity through creating conducive environments, technological change, and innovations; this paper ascertains this through the analysis.

\section{Literature review}

After North's (1990) seminal work, the literature on institutions has grown tremendously, and this has seen an amplified growth in empirical institutional economics, which enhanced the examination of the link between institutional quality and other economic variables (Straub, 2000). Thus, the quality of the institutional environment determines the 
effectiveness of the arrangements that exist between actors. Since humans set up the rules - Acemoglu and Robinson (2012) distinguish between political and economic institutions. The structure of the state and the political decision-making process creates political institutions whose role is to create a conducive environment. These shape the political process and legal environment and influence the behaviour of politicians, parties, and other interest groups.

In contrast, economic institutions refer to property and contract laws and transaction costs that orchestrate economic interactions. Interestingly, political institutions shape economic institutions. To this end, inclusive political and economic institutions (incentivize citizens, thus leading to technological innovations and human development) are prerequisites for sustained prosperity instead of extractive institutions, which only benefit the ruling elite, and have no incentives for citizens to participate in the economy actively.

Subsequently, North (1990) identified channels through which institutions influence economic growth and its effects. Firstly, weak institutions tend to directly reduce the efficiency of investments, thus creating an environment of uncertainty where advanced technology use and property rights protection are not enforced. Secondly, institutional frameworks can indirectly affect economic growth through rising transaction costs resulting from corruption and rent-seeking behavior which ultimately impedes investments.

\section{Empirical Analysis}

Several studies have supported and confirmed a positive relationship between economic performance and institutional quality (Hall and Jones, 2013; Acemoglu et al., 2005; Rigobon and Rodrik, 2004; Easterly and Levine, 2003; Rigobon and Rodrik, 2004). However, although the quality of institutions remains crucial, particularly their certainty and credibility in providing a solid foundation for economic growth, there is still no clear conclusion in the literature regarding its diffusion mechanism and its effect on economic growth. For instance, there exist three strands of literature regarding the effect of institutional quality on economic growth. For instance, in the first strand, some scholars support the view that institutional quality enhances economic growth through creating an enabling environment: ( see: Tamilina and Tamilina, 2014 ; Scully, 1988; Knack and Keefer, 1997; Aron, 2000;, Henisz, 2000; Glaeser et al., 2004; Djankov, McLiesh and Ramalho, 2006; Acemoglu and Robinson, 2012a; Acemoglu et al., 2005; Mbulawa, 2015; and Bruinshoofd, 2016). Similarly, Farole, Rodrí-guez-Pose, and Storper (2011) concur, and add that imperfect institutions adversely affect economic growth by giving rise to rent-seeking behavior and may inhibit potential growth resources such as the provision of public goods, and distort resource allocation, which can lead to unproductive investments and ultimately impede growth (Vijayaraghavan and Ward, 2011). Consistent with the above, Afonso and Jalles (2012) find that a one-unit improvement in the quality of institutions leads to a 0.22 unit rise in per capita GDP, holding other things constant. Higbee and Schmid (2004) add 
that the rule of law and solid legal systems are prerequisites for growth in developing economies; otherwise, corruption weakens the law and adequate property rights protection, thereby perpetuating uncertainty and ultimately aggravating higher transaction costs.

Furthermore, Sondermann (2016) reveals that countries with strong institutions develop flexibility towards economic shocks - not only do they bring about resilience but also promote product diversification (Boschma and Capone, 2015). By implication, the Covid 19 effects on economic performance are an indication that African countries have weak institutions as they showed a lack of flexibility and product differentiation. Additionally, (Shah \& Iqbal, 2008) asserts that poor quality institutions divert scarce resources from productive to unproductive sectors, thus promoting rent-seeking behaviour while strong institutions promote inclusive growth. This implies that some countries may still experience lower growth rates even with a sound financial base due to weak institutions (Mbulawa, 2015). Hall and Jones (2013) report that differences in educational attainment, capital accumulation, productivity, and income disparities observed globally are triggered by differences in the quality and nature of institutions.

The second strand of literature finds different results; for instance, Rodrik (2000) and Williamson (2009), find no evidence of a causal relationship, and thus conclude that institutional quality does not matter for economic growth. Siyakiya (2017) concurs with this view, pointing out that countries like China and India have experienced higher growth levels without institutional reforms. Other vital determinants that the literature has identified include trade openness, inflation, financial development, investment, and education levels.

\section{Operationalizing institutional quality}

Defined as the 'rules of the game', these are humanly devised constraints that structure human interactions, including formal rules and informal constraints that shape human behaviour; institutions must be viewed as a prerequisite for economic success and long run progress. Thus, institutional quality is measured as an explanatory variable to economic performance, which it influences. Given the difficulties in defining institutional quality, this variable is also challenging to measure as it entails a wide range of factors; therefore, for objectivity and replication purposes, publicly accessible data is used. An operationalized institutional variable should be interpreted as a relative score as it depicts an institutional level compared to the global average and then is standardized by the global discrepancy around this average.

Based on the reviewed literature, this paper measures institutional quality as a contextual variable that allows economies to generate, adapt, and absorb international best practices and production techniques, rather than an additional factor of production. 


\section{Methodology}

This section describes the research methodology for this study. An explanation about the data sources, definitions of variables, predicted directions of the relationship between and predictor variables and the test model for hypothesis testing will be provided.

\section{Data}

This paper uses data generated from the World Development Indicators (WDI) database, International Monetary Fund (IMF) financial development index database, and the Worldwide Governance Indicators (WGI) database. The data for the dependent variable and other macroeconomic variables are all drawn from the WDI database. To measure institutional efficiency, an extensive data set constructed by Kaufmann \& Zoido-lobatón, (1999) available as Worldwide Governance Indicators (WGI) was used. The WGI is already expressed as standardized indicators and is constructed from data sources that include expert judgement and surveys of households and businesses. Thus, they reflect the quality of governance as perceived by expert professionals and economic agents more generally, rather than as a narrow view of the laws on the books. The estimates for governance indicators range from -2.5 to +2.5 , with higher values corresponding to better governance while lower values indicate poor institutional quality. This measure of institutions has been extensively used in the literature; for example, Mcmillan, Rodrik, \& Welch, (2002); Easterly and Levine (2003); and more recently Kuncic (2013); and (Chapfuwa, 2020) all use the Worldwide Governance Indicator. Annual estimates are used to track improvements or deterioration over time.

\section{Model Specification}

This study is based on a panel data estimation which analyses the dynamic behaviour of parameters and considers heterogeneity explicitly through allowing subject-specific variables such as countries or firms (Gujarati, 2012). Panel data is also preferred for its power and efficiency over time-series and cross-section data as far as available evidence is concerned (Baltagi and Kao, 1999). The choice of explanatory variables is informed by the literature reviewed and the availability of data for the observed period; thus, based on the literature, the association between institutional quality and economic performance in the SADC region is modelled as follows:

GDP per capita growth = $f$ (institutional quality, financial development, gross fixed capital formation, foreign direct investment inflows, natural resource availability, inflation, trade openness, human capital).

The dependent variable GDP per capita growth measured as a percentage change in per capita growth annually represents economic performance in the region - the main explanatory variables include institutional quality, financial development, domestic investment, and foreign direct investment. Institutional quality measures the quality of 
governance in the SADC region as measured by a composite index consisting of six governance indicators. These include control of corruption (the degree to which public power is used for private gain), government effectiveness (the effectiveness of government policies), rule of law (the confidence in the rule of society and contract enforcement in the host country); the voice of accountability (The degree of civil liberties and independence of media); political stability (citizens' ability to peacefully select and replace those in power and the extent to which government is stable); and regulatory quality (the responsiveness of the market). The estimates for all the governance components range between -2.5 (weak governance) and +2.5 (good governance). Theoretically, the higher the quality, the higher the level of inward FDI.

In addition, financial development is measured as a comprehensive index for financial market development and financial institutions' development in the region. This measure considers the depth, access, and efficiency of financial institutions and financial markets; gross fixed capital formation as a percentage of GDP is used as a proxy for domestic investment; foreign direct investment net inflows as a percentage of GDP. The study controls for resource endowment, macroeconomic stability, and trade openness in the region. Thus, natural resource availability measured by total natural resources rents as a percentage of GDP is used as a proxy; macroeconomic stability is measured by the annual percentage of consumer prices (inflation); trade openness is measured by trade as a percentage of GDP, and human capital is measured by secondary school enrollment.

Based on the theoretical framework, the empirical model for the study is specified as follows:

$$
Y_{i t}=\propto_{0}+\varphi I_{i t}+\theta K_{i t}+\beta X_{i t}+\varepsilon_{i t}
$$

Where $Y_{i t}$ Represent GDP growth rate of country $i$ at period $t$. $I_{i t}$ represents the institutional quality index (INS Index) and $K_{i t}$ indicates other explanatory variables which include financial development, domestic investment and foreign direct investment, and $X_{i t}$ is the set of control variables, $\varepsilon_{i t}$ is the disturbance term that is assumed to be serially uncorrelated and orthogonal to the explanatory variables. The vector of control variables $X$ includes inflation (INF) and trade openness (TO), Human capital (HC) and natural resource availability (NR).

The selected variables have been extensively used in the economic growth literature, as identified by (Li et al., 2010) Mankiw, Romer, and Weil (1992); Levine and Renelt (1992); Barro, 1997); and Saima Nawaz, Nasir Iqbal and Muhammad Arshad Khan (2013). Noteworthy, other variables such as the infrastructure quality, and the colonial history of the country have also been included in some studies, however, they could not be measured in this study due to data constraints.

Thus, the central panel data model adopted to examine the role of institutional quality on economic performance is expressed as regression as follows: 
GDP per capita growt $h_{i t}=\alpha_{0}+\alpha_{1} I Q_{i t}+\alpha_{2} F D_{i t}+\alpha_{3} G F C F_{i t}+\alpha_{4} F D I_{i t}+\alpha_{5} I N F_{i t}+\alpha_{5} T O_{i t}+$ $\alpha_{5} N R_{i t}+\alpha_{5} H C_{i t}+\varepsilon_{i t}$

To examine the effect of individual governance indicators on economic performance in the region, the following equation is estimated:

$$
\begin{aligned}
& \text { lGDPgrowth }_{i t}=\alpha_{0}+\alpha_{1} C C_{i t}+\alpha_{2} G E_{i t}+\alpha_{3} R L_{i t}+\alpha_{4} V A_{i t}+\alpha_{5} P S_{i t}+\alpha_{6} R Q_{i t}+ \\
& \alpha_{7} F D_{i t}+\alpha_{8} G F C F_{i t}+\alpha_{9} N R_{i t}+\alpha_{10} I n f_{i t}+\alpha_{11} T O_{i t}+\alpha_{12} H C_{i t}+\varepsilon_{i t}
\end{aligned}
$$

Where $\mathrm{i}=1 \ldots . \mathrm{n}$ represents the number of cross-sectional units; $\mathrm{t}=1 \ldots . . \mathrm{n}$ represents the period under study. lGDPgrowth is the economic performance variable after taking the log to generate better estimation results, $\alpha_{0}$ is a constant and $\alpha_{1}-\alpha_{12}$ represent the slope of coefficients for country i at time $t$, while $\varepsilon_{i t}$ is the error term.

Table 1: Expected Signs

\begin{tabular}{ll}
\hline Variable & Expected sign \\
\hline Foreign direct investment & + \\
Gross fixed capital formation & + \\
Trade openness & + \\
Inflation & - \\
Natural resource availability & \pm \\
Governance index & - \\
\hline Education & + \\
\hline
\end{tabular}

In Equation (4), institutional quality is expected to have a negative coefficient given the poor state of governance in the region, while domestic and foreign investments, trade openness, human capital and government size are expected to have positive coefficients. Inflation is expected to be negative, while natural resource availability can be negative or positive.

\section{Diagnostic Tests}

Diagnostic tests are crucial in panel data to ensure that proper estimation techniques are applied. It is worth noting that this study estimates a micro panel, that is, large N (15) and small T (10). Given the nature of the panel, issues surrounding panel unit root tests and panel cointegration do not come into play (Baltagi, Bresson, Chaturvedi, \& Lacroix, 2018)therefore, no unit root and cointegration tests were conducted; however, the following diagnostic tests were run.

A pairwise correlation and the variance inflation factor (VIF) and tolerance were run to detect multicollinearity in the regression. The VIF quantifies the extent of inflation in variance. For example, a VIF of 1 implies no collinearity, and thus variances are not inflated; 
however, a VIF value of more than 4.0 or by tolerance less than 0.2 then signals severe multicollinearity to be addressed. Upon detecting multicollinearity among governance variables, the principal component analysis was applied.

The Breusch Lagrange multiplier (LM) test is conducted to test the hypothesis that variances across countries are zero - and cross-sectional dependence is examined using the Pesaran cross-sectional dependence test. The null hypothesis for this test is that residuals are not correlated - a significant $p$-value implies the rejection of the null hypothesis.

A modified Wald test statistic was conducted to detect group-wise heteroscedasticity in the residuals of a fixed effect regression model. The null hypothesis for this test is that each error term's variance is constant or homoscedastic, while the alternative hypothesis is that the error variances are not equal.

Serial correlation in a data set occurs when the disturbance terms from different periods are correlated - this is prevalent in time-series research where errors associated with a given time overlaps into future periods (Williams, 2015). Serial correlation in panel data models leads to biased standard errors and ultimately inefficient results. A Woodridge test for serial correlation was run; the null hypothesis is no serial correlation.

A panel study cannot assume that all cross-sectional units are independent of each other, particularly in regional groupings where countries tend to be interdependent. Furthermore, cross-sectional dependence negatively affects both Fixed Effects and Random Effects estimates, thus leading to biased standard errors, and therefore necessitating robust standard errors. As a result, a Pesaran CD test (Cross-sectional dependence) test was run to test whether the residuals are correlated across the member countries. The null hypothesis for this test is that residuals are not correlated - a significant p-value implies a rejection of the null hypothesis.

\section{Estimation technique}

This paper adopts a panel data estimation technique to examine the effect of institutional quality on econometric performance. This technique allows for combining periods and provides more reliable and robust inference. The panel data estimation technique is considered an efficient analytical method since it combines different cross-sections and periods and exploits within-group variation. It controls the average differences across countries in both observable and unobservable variables, thus removing omitted variable bias. This technique assumes that the idiosyncratic term is uncorrelated with all observations.

The panel data combines cross-sectional and time-series dimensions, making it relatively robust with more degrees of freedom, and less collinearity, while also providing more robust and reliable inferences than a time-series or cross-sectional data alone (Hsiao, 2003). However, despite the identified advantages, panel data are afflicted with serial correlation, autocorrelation, heteroscedasticity, cross-sectional dependence, and endogeneity - all these issues lead to biased and unreliable estimates. Although there are 
various techniques in the literature such as ordinary least squares, generalized least squares, fixed effects, and random effects - in the presence of the above panel data issues, the above methods are weakened, and thus, produce biased and inefficient estimates. To remove the individual heterogeneity from the fixed effects model $y_{i t}=\left(\alpha+u_{i}\right)+$ $X_{i t}^{\prime} \beta+v_{i t}$ - Dynamic panel models become crucial. Panel regression models are referred to as dynamic because they incorporate a lagged dependent variable, (Baltagi et al., 2018). Dynamic panel models comprise one or more lagged dependent variables, allowing the modelling of a partial adjustment mechanism.

Thus, this paper employs the system GMM panel data technique developed by Arellano, Blundell and Bond (1998) and Roodman, (2009). The application of this technique follows the Monte Carlo evidence which suggests that when the time dimension is short and the dependent variable is persistent, the more significant number of moment conditions leads to precision while also reducing sample bias.

This technique uses uncorrelated instruments with the error term to control for the endogeneity of the lagged dependent variable. It finds the parameters estimates by maximizing the moment restriction, and controls for omitted variable bias, unobserved heterogeneity and dramatically improves efficiency in the model. In essence, the GMM considers the time observable country-specific effects, including lagged explanatory variables and the possibility that all explanatory variables are homoscedastic, crosssectional independent, and serially independent (Blundell, Bond, and Windmeijer, 2000). Furthermore, the system-GMM technique combines the first-difference operator with the estimator in levels to form a relatively efficient system estimator. To this end, the difference equation retains the same instruments. In contrast, in the levels equation, predetermined and endogenous variables are instrumented with appropriate lags of their first differences, and strictly exogenous variables directly enter the instrument matrix for use in the levels equation (Blundell and Bond 1998). The system GMM estimator has been widely employed in the empirical literature examining the effect of institutional quality on economic performance - thus, this paper adopts this model to examine the effect of institutions on economic performance in the SADC region.

Thus, the model employed in this paper is specified as follows:

$$
Y_{i t}=\varnothing Y_{i t-1}+\beta X^{\prime}{ }_{i t}+y Z^{\prime}{ }_{i t}+d_{t}+\varepsilon_{i t}
$$

Where $Y_{i t-1}$ is the lag of the dependent variable, $X^{\prime}{ }_{i t}$ is the vector of strictly exogenous variables, while $Z^{\prime}{ }_{i t}$ is the vector of predetermined covariates and endogenous covariates, $d_{t}$ is the unobserved group-level effect, and $\varepsilon_{i t}$ is the error term. The basic assumption here is that $d_{t}$ and $\varepsilon_{i t}$ are independent for each unit overall $\mathrm{t}$, and that there is no autocorrelation in the $d_{t}$.

\section{Empirical Results}


This section presents and analyses the results of the study. Data analysis commences with the descriptive statistics analysis, then diagnostic analysis, and the main results.

\section{Descriptive Statistics}

\section{Principal component analysis}

Table 2 presents eigenvalue rankings according to their eigenvectors from the highest to the lowest to determine the principal component in order of significance.

Table 2: Principal component analysis

\begin{tabular}{ccccc} 
Component & Eigenvalue & Difference & Proportion & Cumulative \\
\hline Comp1 & 5.29474 & 5.01683 & 0.8825 & 0.8825 \\
Comp2 & .277908 & .0848566 & 0.0463 & 0.9288 \\
Comp3 & .193051 & .063977 & 0.0322 & 0.9610 \\
Comp4 & .129074 & .0588999 & 0.0215 & 0.9825 \\
Comp5 & .0701745 & .035124 & 0.0117 & 0.9942 \\
\hline Comp6 & .0350505 &. & 0.0058 & 1.0000 \\
\hline
\end{tabular}

Source: author's computations

The results indicate that the first component has the highest eigenvalue (5.29) and thus explains most (88\%) of the variation in the data. The first two components together explain 93 percent of the variation. However, only the first component is significant with a higher eigenvalue of 5.29; thus, the first component was used to compile the composite index.

\section{Summary statistics}

Table three presents descriptive statistics for the data. As seen on the table, the total number of observations is 165 for most variables, and 132 for human capital due to data constraints in some member states.

Table 3: summary statistics

\begin{tabular}{llllll}
\hline Variables & N & Mean & S-Deviation & Min & Max \\
\hline FDI & 165 & 5.14 & 7.73 & 6.37 & 57.84 \\
Trade openness & 165 & 88.99 & 37.89 & 32.24 & 225.0 \\
GDP per capita growth & 165 & 1.89 & 3.47 & -9.44 & 18.07 \\
Financial development & 141 & 0.221 & 0.16 & 0.35 & 0.65 \\
Gov-index & 165 & -1.76 & 1.03 & -1.74 & 1.68 \\
Gross fixed capital formation & 165 & 74.27 & 47.34 & 1 & 156 \\
Inflation & 165 & 83 & 47.78 & 1 & 165 \\
Natural resource & 165 & 81.06 & 46.80 & 1 & 162 \\
Human capital & 132 & 49.80 & 36.35 & 1 & 114 \\
Number of panels & 13 & 13 & 13 & 13 & 0 \\
\hline
\end{tabular}

Source: Author's calculations 
Data shows that the average for FDI in the region over the observed period is 5.15 with a standard deviation of 7.73. In addition, institutional quality in the region shows an average of -1.76 with a standard deviation of 1.03 . This negative mean is already indicative of the weak quality of governance in the region. It will be interesting to see how this institutional quality influences economic performance in the region.

\section{Pairwise Correlation}

Table 4 below presents the correlation matrix between economic performance and explanatory variables.

Table 4: Pairwise Correlation

\begin{tabular}{|c|c|c|c|c|c|c|c|c|c|}
\hline & GDPpercapita & FDI & TO & FD & GFCF & INF & NR & $\mathrm{HC}$ & Gindex \\
\hline GDPpercapita & 1.0000 & & & & & & & & \\
\hline FDI & 0.1801 & 1.0000 & & & & & & & \\
\hline TO & 0.2378 & 0.4139 & 1.0000 & & & & & & \\
\hline FD & -0.0298 & -0.0909 & 0.1512 & 1.0000 & & & & & \\
\hline GFCF & 0.0365 & 0.2996 & 0.1140 & -0.1459 & 1.0000 & & & & \\
\hline INF & -0.1884 & -0.0133 & -0.2231 & 0.0201 & 0.1425 & 1.0000 & & & \\
\hline NR & -0.1944 & -0.2578 & -0.5032 & -0.1714 & 0.1443 & 0.2371 & 1.0000 & & \\
\hline $\mathrm{HC}$ & 0.2251 & 0.0460 & 0.5017 & 0.4513 & -0.2193 & -0.1379 & -0.3344 & 1.0000 & \\
\hline Gindex & -0.2157 & -0.0284 & 0.2422 & 0.7519 & -0.1645 & 0.0205 & -0.2024 & 0.4901 & 1.0000 \\
\hline
\end{tabular}

As expected, FDI, trade openness, domestic investments and human capital are positively correlated with GDP per capita, while financial development, inflation, natural resource availability and governance quality have negative coefficients.

\section{Variable inflation factor}

The VIF quantifies the extent of inflation invariance, and the coefficients' variances are inflated when multicollinearity exists.

Table 5: Variable inflation factor

\begin{tabular}{lll}
\hline Variable & VIF & $\mathbf{1 / V I F}$ \\
\hline FDI & 1.22 & 0.81 \\
Trade openness & 1.31 & 0.77 \\
Human Capital & 1.19 & 0.84 \\
Gov-index & 1.14 & 0.87 \\
Financial development & 1.21 & 0.82 \\
Gross fixed capital formation & 1.07 & 0.94 \\
Inflation & 1.05 & 0.95 \\
Natural resource & 1.34 & 0.74 \\
Mean VIF & $\mathbf{1 . 1 7}$ & $\mathbf{0}$ \\
\hline
\end{tabular}

Source: Author's calculations using the World Bank's WDI database. 
If the VIF is less than 2, it implies that there is no collinearity and thus variances are not inflated; however, a VIF value of more than 3.0 or tolerance of fewer than 0.2 signals severe multicollinearity which needs to be addressed before the regression analysis). Thus, the lower the VIF, the better. These results suggest that there is no multicollinearity in the regression.

\section{Diagnostic Tests}

Several diagnostic tests were conducted to understand the data better and identify appropriate estimation techniques for the analysis. It should be noted that the study did not engage in panel unit root tests as well as cointegration tests since this is a micro panel study. The results of the various tests are presented below.

Table 6: Various diagnostic test results

\begin{tabular}{llc}
\hline Test & Value & P - value \\
\hline Simple chow test & $\mathrm{F}(9,92)=4,06$ & 0.0002 \\
Hausman test & 2,67 & 0.0012 \\
Heteroscedasticity test & 7,92 & 0.0023 \\
Serial correlation & 0,21 & 0.6603 \\
Pesaran CD test & 2,56 & 0.0105 \\
\hline
\end{tabular}

Source: Author's calculations

The null hypothesis for the F-test is that the data are poolable, which implies that the slopes are the same for all the cross-section units. The null hypothesis is rejected based on the chow test results, suggesting that fixed effects are the appropriate model. The Hausman test compares FE and RE models, and the null hypothesis for this test is that there is no correlation concerning individual effects and regressors in the model (Hausman, 1978). If the null hypothesis of no correlation is rejected, it can then be concluded that individual effects $u_{i}$ are significantly correlated with regressors in the model, and thus, the RE model is not appropriate. The Hausman test results $(0.0012)$ reject $H_{0}$, thus suggesting a correlation between individual effects and regressors. The null hypothesis for the adjusted Wald test statistic (heteroscedasticity) is that variances across countries are homoscedastic. As presented in Table 5, the null hypothesis of homoscedastic variances is rejected and thus conclude that variances are not constant and thus, robust standard errors became necessary. For serial correlation, the null hypothesis is no serial correlation - the $p$-value is 0.6603 . Thus, we fail to reject the null and conclude no serial correlation among the variables. Lastly, the Pesaran (CD) test was conducted to test cross-sectional dependence, and the null hypothesis is that residuals are not correlated. The $p$-value of 0.0105 suggests that we reject the null and conclude that the residuals are correlated; 
thus, cross-sectional dependence. On this basis, the system GMM technique was adopted to improve efficiency and omitted variable bias.

\section{Regression results}

Table 7 presents the estimation results of the models. The first equation is the fixed effects model with time effects. However, due to the results of the Modified Wald test for groupwise heteroscedasticity and Pesaran CD test, equation (2), the fixed effects regression with Driscoll and Kraay standard errors was estimated. These standard errors are robust to all forms of cross-sectional dependence and are heteroscedasticity consistent. Although Equation two could be considered appropriate and robust, it did not address the endogeneity problem that persisted - this necessitated the application of the dynamic panel models, namely, the difference GMM (3) and two-step GMM (4). Based on the adopted methodology, only Equation (4) results are interpreted.

As presented in Table 7 Equation (4), the two-step system GMM technique was adopted to examine the effect of institutional quality on economic performance in the SADC region. Here the primary explanatory variable is institutional quality while GDP per capita growth is the dependent variable, and for robustness checks, GDP growth rate was also run as a dependent variable. Table 7 presents the estimated coefficients, and their robust standard errors in parenthesis and asterisks are used to indicate the significance level. Concerning the two-step system GMM results, the lagged dependent variable (LI_GDP per capita growth) coefficient is between $0-1(0,326)$ - this is consistent with the theory, which stipulates that a model is efficient if the lagged dependent variable's coefficient ranges between 0 and 1 (Baltagi, Bresson, Chaturvedi, and Lacroix, 2018).

The study employed four main information benchmarks to evaluate the strength of estimated models, namely, a Sargan-Hansen test for the over-identification of instruments was conducted to validate these estimates' statistical power. The null hypothesis for the test is that all the instruments are valid; that is, there is no over-identification. As seen in Table 7 below, the Sargan-Hansen test results indicate the absence of instrument proliferation with a $p$-value of 0.542 , which suggests valid instruments. 
Table 7: Results

\begin{tabular}{|c|c|c|c|c|}
\hline & (1) & (2) & (3) & (4) \\
\hline VARIABLES & $\mathrm{FE}$ & FE - Drisk/Kraay & Diff GMM & 2-step GMM \\
\hline \multirow[t]{2}{*}{ FDI } & $0.0900 * *$ & $-0.0900^{*}$ & 0.147 & 0.222 \\
\hline & $(0.0404)$ & $(0.0464)$ & $(0.145)$ & $(0.198)$ \\
\hline \multirow[t]{2}{*}{ Trade openness } & 0.00244 & 0.00244 & $0.348^{* * *}$ & $0.0895 * *$ \\
\hline & $(0.0184)$ & $(0.00767)$ & $(0.0955)$ & $(0.472)$ \\
\hline \multirow[t]{2}{*}{ Financial Development } & -0.88 & $-0.69 *$ & 0.315 & $0.151^{* * *}$ \\
\hline & $(1.920)$ & (1.625) & $(1.13)$ & (3.13) \\
\hline \multirow[t]{2}{*}{ Governance index } & $-3.363 * *$ & $-3.363^{* * *}$ & -2.817 & $-0.713 * * *$ \\
\hline & $(1.400)$ & $(0.747)$ & (3.247) & $(2.003)$ \\
\hline \multirow[t]{2}{*}{ GFCF } & 0.0772 & 0.00772 & 0.4226 & 0.1850 \\
\hline & $(0.0798)$ & $(0.00969)$ & $(0.3106)$ & $(0.082) * *$ \\
\hline \multirow[t]{2}{*}{ Inflation } & -0.0388 & 0.00388 & -0.0338 & -0.0413 \\
\hline & $(0.00579)$ & $(0.00246)$ & $(0.0314)$ & $(0.0712)^{* *}$ \\
\hline \multirow[t]{2}{*}{ Natural resource } & -0.0489 & -0.00489 & -0.008 & -0.174 \\
\hline & $(0.00965)$ & $(0.00605)$ & (0.0153) & $(0.230)^{* *}$ \\
\hline \multirow[t]{2}{*}{ Human capital } & 0.00426 & -0.00426 & 0.0949 & 0.2367 \\
\hline & $(0.0107)$ & $(0.00357)$ & $(0.529)$ & (0.7393) \\
\hline \multirow[t]{2}{*}{2010.} & $2.075^{* *}$ & $2.075^{* * *}$ & & \\
\hline & $(0.851)$ & $(0.0361)$ & & \\
\hline \multirow[t]{2}{*}{2011.} & $3.538 * * *$ & $3.538 * * *$ & & \\
\hline & $(0.863)$ & $(0.171)$ & & \\
\hline \multirow[t]{2}{*}{2012.} & $2.736 * * *$ & $2.736 * * *$ & & \\
\hline & $(0.894)$ & $(0.340)$ & & \\
\hline \multirow[t]{2}{*}{2013.} & $2.602 * * *$ & $2.602 * * *$ & & \\
\hline & $(0.875)$ & $(0.188)$ & & \\
\hline \multirow[t]{2}{*}{2014.} & $2.221^{* *}$ & $2.221 * * *$ & & \\
\hline & $(0.888)$ & $(0.258)$ & & \\
\hline \multirow[t]{2}{*}{2015.} & 0.983 & $0.983^{* *}$ & & \\
\hline & $(0.930)$ & $(0.337)$ & & \\
\hline \multirow[t]{2}{*}{2016.} & 0.313 & 0.313 & & \\
\hline & $(0.972)$ & $(0.424)$ & & \\
\hline \multirow[t]{2}{*}{2017.} & 0.289 & 0.289 & & \\
\hline & $(0.906)$ & $(0.279)$ & & \\
\hline \multirow[t]{2}{*}{2018.} & 0.341 & 0.341 & & \\
\hline & (0.939) & $(0.491)$ & & \\
\hline \multirow[t]{2}{*}{2019.} & 0.0552 & 0.0552 & & \\
\hline & $(0.958)$ & $(0.391)$ & & \\
\hline \multirow[t]{2}{*}{ L.GDPpercapitagrowth } & & & $0.230^{* *}$ & $0.326 * * *$ \\
\hline & & & $(0.256)$ & $(0.133)$ \\
\hline \multirow[t]{2}{*}{ Constant } & 3.258 & $6.1712^{* * *}$ & & $7.537^{* *}$ \\
\hline & (3.765) & $(1.5598)$ & & $(3.070)$ \\
\hline Observations & 110 & 110 & 115 & 128 \\
\hline R-squared & 0.380 & 0.38 & & \\
\hline$A R 1$ & & & 0.473 & 0.033 \\
\hline$A R 2$ & & & 0.216 & 0.601 \\
\hline Hansen/Sargan & & & 0.821 & 0.542 \\
\hline Number of instruments & & & 10 & 11 \\
\hline Number of panel & 10 & 10 & 13 & 13 \\
\hline
\end{tabular}

Robust standard errors in parenthesis $* * * p<0.01, * * p<0.05, * p<0.1$ Source: Author's analysis using Stata

Dynamic panels also test for autocorrelation; there is the first-order autocorrelation, denoted by $A R_{1}$ and second order denoted by $A R_{2}$. The null hypothesis for $A R_{1}$ is that 
there is the first-order autocorrelation between the instruments and the error term - while the null hypothesis for $A R_{2}$ is that there is no second-order autocorrelation. Table 7 shows a p-value of 0.033 for $A R_{1}$ which rejects the null of the first-order autocorrelation. For $A R_{2}$ the $p$-value is 0.601 , and thus we fail to reject the null of no first-order correlation.

Concerning the coefficients, FDI, trade openness, financial development, gross fixed capital formation, and human capital have positive coefficients, implying that these variables stimulate economic growth in the region. However, despite being positively correlated to growth and consistent with the expectation, not all these variables are statistically significant; for instance, FDI and human capital have insignificant coefficients. On the other hand, the governance index, inflation, and natural resource availability have negative and statistically significant coefficients.

According to these results, trade openness is significant at a 5 percent level and explains 9 percent of the variation in GDP in the region - this implies that a unit increase in trade openness in the region subsequently leads to a 9 percent rise in economic growth. This is consistent with the theory that suggests that trade liberalization is an engine for economic prosperity. For instance, the Hector-Ohlin and Samuelson theory emphasizes the importance of comparative advantage whereby countries specialize in producing goods that the required resources are available. Consistent with this, the neoclassical theory concurs that trade liberalization stimulates economic growth.

In addition, financial development is statistically significant at 1 percent and explains 15 percent of the variation in GDP growth in the region. By implication, a unit increase in financial development leads to a 15 percent rise in economic performance. This variable is measured as a comprehensive index for financial market development and financial institutions' development in the region, which considers the depth, access, and efficiency of financial institutions and financial markets. This is a crucial finding given that the region ratified financial liberalization reforms by removing restrictions on foreign ownership and the deregulation of offshore investments; and allowing foreign investors to borrow money from the region's financial institutions to finance their innovative activities within the region. Noteworthy, member states are at different levels as far as financial development is concerned - of particular concern, member states still have different financial systems, which might be the reason behind illicit financial flows, which is still a considerable challenge in the region. Therefore, harmonization of the systems may reduce segmentation and unleash the growth potential in the region.

Furthermore, gross fixed capital formation, a proxy for domestic investment, is statistically significant at a 5 percent level and explains 19 percent of the variation in economic growth in the region. This finding is consistent with the theory that capital deepening stimulates economic growth. 
Additionally, inflation, which is a proxy for macroeconomic stability, is negative and statistically significant at 5 percent - this variable explains 4 percent of the variation in growth rates. By implication, in the absence of macroeconomic stability due to rising inflation rates, GDP weakens. These results are theoretically correct, particularly as they pertain to the SADC region, given that member countries have been trying to harmonize their stability-oriented policies to achieve macroeconomic convergence but are still confronted with challenges in this regard.

Natural resource availability is negative and significant at 5 percent, and this variable explains 17 percent of the variation in growth rates. Contrary to the view that natural resource availability in developing countries stimulates growth, these findings are consistent with the literature that posits that resource endowment could sometimes be a 'curse', particularly for developing economies that generate undesirable developmental outcomes, such as poor economic performance leading to rising corruption levels.

Lastly, the governance index is negative and significant. By implication, a unit increase in weak governance leads to a 7 percent deterioration in economic growth. Thus, the quality of governance and the nature of the political framework in the region do not promote growth; that is, institutions fail to create an attractive and enabling institutional environment for economic growth, thus leading to poor economic performance in the region. The region is plagued by high levels of corruption, ineffective policies, political instability, the weak rule of law and lack of accountability - and these are responsible for poor GDP per capita growth levels. These findings are consistent with Acemoglu et al. (2005), who argue that the institutional quality impact is contextual and provides an enabling environment for growth when sufficiently of high quality while also driving the total factor productivity (Hall \& Jones, 2013), or hampers growth if the opposite happens. Consistent with this, North (1990) maintains that efficient, well-developed and uncorrupt institutions guarantee that labour can only be used for productive purposes and not wasted in rent-seeking activities, which lead to higher economic growth (North (1990).

\section{Conclusion and recommendations}

Theoretical predictions on the institutions' economic performance nexus are inconclusive and mixed. While Acemoglu et al and North (1990) argue that institutional quality determines economic performance and the reverse is untrue, Glaeser et al. (2004) argue that high levels of economic development allow economies to adopt high quality and inclusive institutional arrangements. This paper attempted to test these alternative theoretical arguments in the context of the SADC region. Through a panel data set covering 15 member states over the period $2009-2019$, the study concludes that weak governance impedes economic performance in the region. Thus, the poor institutional quality is also linked to the adverse effects of natural resources availability and macroeconomic 
instability and ultimately stifles growth through limiting inflows to resource-seeking and market-seeking investments. To this end, addressing weak or poor institutional quality in the region is a prerequisite for attaining higher economic growth levels and achieving the region's developmental goals.

\section{Disclosure statement}

The author declares that there is no conflict of interest.

\section{References}

Acemoglu, D., Johnson, S., \& Robinson, J. A. (2005). Institutions as a Fundamental Cause of Long-Run Growth. Volume 1A. Handbook of Economic Growth, I(05), 375-472.

Acemoglu, D., \& Robinson, J. (2012a). Why nations fail. In Crown Publishers, Crown publishing group, a division of Random House, Inc., New York (Vol. 53). https://doi.org/10.1017/СBO9781107415324.004

Acemoglu, D., \& Robinson, J. (2012b). Why nations fail - the origins of power, prosperity and poverty. In Crown Publishers, Crown publishing group, a division of Random House, Inc., New York (Vol. 53). https://doi.org/10.1017/СBO9781107415324.004 Afonso, A., \& Jalles, J. T. (2012). Growth and Productivity: The Role of Government Debt. SSRN Electronic Journal. https://doi.org/10.2139/ssrn.1893687

Alemu, A. M. (2015). Quality of Institutions and FDI Inflow: Evidence from Asian Economies. Paper Presented at the Meeting of IDASA/FREDSKORPSET Research Programme Governance and Democracy. Parktonian Hotel, Braamfontein, Johannesburg, South Africa. 2 - 4 May, 35 47. Retrieved from http://gsis.korea.ac.kr/wpcontent/uploads/2015/06/16-1-03-Aye-Mengistu-Alemu.pdf

Aron, J. (2000). Growth and institutions: A review of the evidence. World Bank Research Observer, 15(1), 99-135. https://doi.org/10.1093/wbro/15.1.99

Aysan, A. F., Nabli, M. K., \& Véganzonès-Varoudakis, M.-A. (2006). Governance and Private Investment in the Middle East and North Africa. World Bank Policy Research, 1-65.

Aziz, O. G. (2018). Institutional quality and FDI inflows in Arab economies. Finance Research Letters, 25(December), 111-123. https://doi.org/10.1016/j.frl.2017.10.026

Baltagi, B. H., Bresson, G., Chaturvedi, A., \& Lacroix, G. (2018). Robust linear static panel data models using $\varepsilon$-contamination. Journal of Econometrics, 202(1), 108-123. https://doi.org/10.1016/j.jeconom.2017.07.002

Baltagi, B., \& Kao, C. (1999). Nonstationary Panels, Cointegration in Panels and Dynamic Panels: A survey. Center for Policy Research - Working Paper No.16, (9).

Barro, R. . J. and X. S.-M. (1997). Technology diffusion, convergence and growth. Journal of 
Economic Growth, 2, : 1-26.

Barro, R. I. (1994). Democracy and Growth. NBER Working Paper Series, Democracy(4).

Bernard, A. B., \& Jones, C. I. (2019). Productivity Across Industries and Countries: Time Series Theory and Evidence Author ( $s$ ): Andrew B. Bernard and Charles I. Jones Source: The Review of Economics and Statistics, Vol . 78, No . 1 ( Feb ., 1996 ), pp . 135-146 Published by: The MIT . 78(1), 135-146.

Blundell, R., \& Bond, S. (1998). Initial conditions and moment restrictions in dynamic panel data models. Journal For Econometrics, 87(I), 115-143.

Blundell, R., Bond, S., \& Windmeijer, F. (2000). Estimation in dynamic panel data models: improving on the performance of the standard GMM estimator. Working Papeer.

Boschma, R., \& Capone, G. (2015). Institutions and diversification: Related versus unrelated diversification in a varieties of capitalism framework. Research Policy, 44(10), 19021914. https://doi.org/10.1016/j.respol.2015.06.013

Bruinshoofd, A. (2016). Institutional quality and economic performance What are institutions and why are they important for economic development ? Rabo Research, 1-22.

Chapfuwa, D. F. (2020). the Role of Institutions in Determining Fdi Flows Into the Sadc Region. 5(June), 1-24. https://doi.org/10.19275/RSEP079

Crawford, S. E. S. (1995). Grammar of Institutions. The American Political Science Review, Vol. 89, pp. 582-600.

Djankov, S., McLiesh, C., \& Ramalho, R. M. (2006). Regulation and growth. Economics Letters, 92(3), 395-401. https://doi.org/10.1016/j.econlet.2006.03.021

Easterly, W., \& Levine, R. (2003). Tropics, germs, and crops: How endowments influence economic development. Journal of Monetary Economics, 50(1), 3-39. https://doi.org/10.1016/S0304-3932(02)00200-3

Farole, T., Rodrí-guez-Pose, A., \& Storper, M. (2011). Human geography and the institutions that underlie economic growth. Progress in Human Geography, 35(1), 58-80. https://doi.org/10.1177/0309132510372005

Glaeser, E. L., La Porta, R., Lopez-de-Silanes, F., \& Shleifer, A. (2004). Do institutions cause growth? Journal of Economic Growth, 9(3), 271-303. https://doi.org/10.1023/B:JOEG.0000038933.16398.ed

Gujarati, D. N. (2012). BASIC.

Hall, R. E., \& Jones, C. I. (2013). Why Do Some Countries Produce So Much More Output Per Worker Than Others ? Author ( $\mathrm{s}$ ): Robert E . Hall and Charles I . Jones Published by : Oxford University Press. The Quarterly Journal of Economics, 114(1), 83-116. https://doi.org/10.1162/003355399555954

Henisz, W. J. (2000). The institutional environment for economic growth. Economics and Politics, 12(1), 1-31. https://doi.org/10.1111/1468-0343.00066

Higbee, J., \& Schmid, F. A. (2004). Rule of Law and. (August), 2004. 
Hsiao, C. (2003). Analysis of panel data, second edition. Economic Society Monographs, University of Cambridge, 34, 1-42.

Javed, O. (2011). Determinants of Institutional Quality: A case study of IMF Programme countries. Munich Personal RePEc Archive, (46733), 6-25.

Kandil, M. (2009). Determinants of institutional quality and their impact on economic growth in the MENA region. International Journal of Development Isuues. International Monetary Fund, Washington, DC, USA, 8(2), 134-167.

Kaufmann, D., \& Zoido-lobatón, P. (1999). Governance Matters October 1999. Policy Research Working Paper, (October), 1-61.

Knack, S. and Keefer, P. (1997). Does Social Capital Have an Economic Payoff ? A CrossCountry Investigation. Published by: Oxford University Press Stable URL: Http://Www.Jstor.Org/Stable/2951271, 112(4), 1251-1288.

Li, Z. Z., Su, C. W., Tao, R., Hao, L. N., Crawford, S. E. S., Ostrom, E., ... Hodgson, G. M. (2010). Why Do Some Countries Produce So Much More Output Per Worker Than Others? Author ( s): Robert E. Hall and Charles I . Jones Published by : The MIT Press Stable URL : http://www.jstor.org/stable/2586948. Rationality, Institutions and Economic Methodology, 48(1), 47-81. https://doi.org/10.1111/1465-5922.t01-1-00003

Masuch, K., \& Moshammer, E. (2016). Working Paper Series Institutions, public debt and growth. (1963).

Mauro, P. (2008). Corruption and Growth. The Quarterly Journal of Economics, 110(3), 681-712.

Mbulawa, S. (2015). Determinants of Economic Growth in Southern Africa Development Community: The Role of Institutions. Applied Economics and Finance, 2(2), 91-102. https://doi.org/10.11114/aef.v2i2.782

Mcmillan, M., Rodrik, D., \& Welch, K. H. (2002). When economic reform goes wrong: Cashews in Mozambique (No. 9117). Cambridge.

North, D. (1990). Institutions, Institutional Change and Economic Performance. Ambridge: Cambridge University Press.

Rigobon, R., \& Rodrik, D. (2004). Rule of law, Democracy, openness and income: Estimating the interrelationships. NBER WORKING Paper Series, 2004, 352.

Rodrik, D. (2000). Institutions for high-quality growth: what they are and how to acquire them. NATIONAL BUREAU OF ECONOMIC RESEARCH, (February).

Roodman, D. (2009). How to do xtabond2 : An introduction to difference and system GMM in Stata. The Stata Journal . Center for Global Development, 9(1), 86-136.

Scully, G. W. (1988). The Institutional Framework and Economic Development Author ( $s$ ): Gerald W. Scully Source : Journal of Political Economy, Vol . 96 , No . 3 ( Jun ., 1988 ), $p p$. 652-662 Published by: The University of Chicago Press Stable URL: https://www.jstor.org/. 96(3), 652-662.

Shah, A., \& Iqbal, K. (2008). A critical review of governance indicators. 
Siyakiya, P. (2017). The Impact of Institutional Quality on Economic Performance: An Empirical Study of Turkey and 28 Countries in the European Union. World Journal of Applied Economics, 3(2), 3-24. https://doi.org/10.22440/wjae.3.2.1

Solow, R. M. (1955). The Production Function and the Theory of Capital. The Review of Economic Studies, 23(2), 101. https://doi.org/10.2307/2296293

Sondermann, D. (2016). Working Paper Series Towards more resilient economies : the role of well - functioning. (1984).

Straub, S. (2000). Empirical Determinants of Good Institutions: Do We Know Anything? Working Paper Series, Research Department. Inter- American Development Bank, (June). https://doi.org/10.2139/ssrn.1817222

Tamilina, L., \& Tamilina, N. (2014). Heterogeneity in Institutional Effects on Economic Growth Theory and Empirical Evidence. The European Journal of Comparative Economics, 11(2), 205-249.

Tralac. (2019). About AGOA.

Tylecote, A. (2016). Review Article Institutions matter : but which institutions ? And how and why do they change? (December 2015), 721-742. https://doi.org/10.1017/S1744137415000478

Vijayaraghavan, M., \& A. Ward, W. (2011). Institutions and Economic Growth: Empirical Evidence from a Cross-National Analysis. Journal of International Trade, 3(4), 4-9. 